\title{
Nascent entrepreneurs of millennial generations in the emerging market of Indonesia
}

\author{
Basuki, Rahmi Widyanti, Ismi Rajiani
}

\begin{abstract}
A B S T R A C T
Objective: The objective of the article is to investigate the empirical linkages between personality, cultural values, and entrepreneurial characteristics and entrepreneurial behaviour in the context of SMEs' run by millennial generations in Indonesia.

Research Design \& Methods: This study used survey methods to reveal the relationship between variables through hypotheses testing on 551 respondents from among SMEs' owners who just started business (nascent entrepreneur) in Banjarmasin, Indonesia, with the use of structural equation modelling.

Findings: Although the results prove that personality, cultural values, and entrepreneurial characteristics significantly affect entrepreneurial behaviour, the entrepreneurial characteristics that distinguish entrepreneur from non-entrepreneurs are rated the lowest. The impact of low self-efficacy, which does not support the implementation of entrepreneurial activities, makes it difficult to justify the millennial entrepreneur respondents are genuine to become the businessman or they are naively pursuing an unfeasible or inoperable opportunity.

Implications \& Recommendations: Since the extant literature is very scarce in fully addressing the new generation of entrepreneurs, our model can be used to identify unique characteristics of millennial entrepreneurs from emerging market countries.

Contribution \& Value Added: Up to this point, the majority of research in the field originated from Englishspeaking countries. The current study provides additional evidence on the entrepreneurial tendency of millennial Indonesians, which contributes to the growing international research on this generation.

\section{Article type: research article}

Keywords: characteristics; personality; cultural values; entrepreneurial; behaviour; millennial JEL codes: M13, N45, R11

Received: 1 October $2020 \quad$ Revised: 29 November $2020 \quad$ Accepted: 13 December 2020
\end{abstract}

\section{Suggested citation:}

Basuki, Widyanti, R., \& Rajiani, I. (2021). Nascent entrepreneurs of millennial generations in the emerging market of Indonesia. Entrepreneurial Business and Economics Review, 9(2), 151-165. https://doi.org/10.15678/EBER.2021.090210

\section{INTRODUCTION}

Previous studies show that the tendency in the development of entrepreneurship is triggered by economic pressures on an individual, who seeks to create employment for himself (Freiling \& Harima, 2019), avoid unemployment (Meyer \& Meyer, 2020), alleviate the frustration from a former job (Duan et al., 2020), and seeks a better life (Chansuchai, 2019) with different results of regarding success (Covin et al., 2020). However, most recent studies on entrepreneurship still focus mostly on old-timers, meaning entrepreneurs born in the 1950s, 1960s, and 1970s (Liu et al., 2019). Thus, it remains unknown whether the current millennial generation is as passionate as the older one in starting new ventures. However, entrepreneurship researchers are very interested in exploring recent business rise and fall. Improved methodological rigour in the determination of nascent entrepreneurs - i.e. businesspeople who recently opened new business (He et al., 2020) - motivates many scholars to analyse the existence of nascent entrepreneurial attempts. 
Examining some notable millennial entrepreneurs like Mark Zuckerberg (Facebook), Brian Chesky (Airbnb), and Kevin Systrom (Instagram), we detected that they exclusively stem from western and developed countries. However, the world's economic movement slowly repositions from the western to the eastern hemisphere and from the northern to the southern hemisphere (Makszin et al., 2020), which is a tendency that may produce millennial entrepreneurs in Indonesia.

Although the millennial generation all over the world has one thing in common - familiarity with digital and information technology - individuals from this generation differ distinctively across different countries. For example, the US millennials are called "pragmatic idealists," after distress caused by several terrorist attacks and the realisation that their country's relative power slowly diminishes (Rauch, 2018). On the other hand, Chinese millennials are described as increasingly maverick, inventive, bold, and prepared to alter the world (BBC News, 2019). Furthermore, millennials from developed countries like the UK or Japan may have an indistinct entrepreneurial viewpoint because of sluggish economic progress of their countries. In the same vein, we consider whether it will be possible to see innovative grassroots entrepreneurs from emerging markets like Indonesia, which demonstrate encouraging entrepreneurial atmosphere in the recent decade (Zamrudi \& Yulianti, 2020). The Global Entrepreneurship Monitor (GEM) defines three dominant reasons or motives why individuals participate in start-ups (Chadha \& Dutta, 2020): High-expectation Entrepreneurship Activity (HEA) conveys all start-ups and newly formed businesses, Opportunity Entrepreneurship Activity (OEA) gathers individuals who perceive a business opportunity and start a business as one of several possible career options, and Necessity Entrepreneurship Activity (NEA) comprises individuals that see entrepreneurship as their last resort and start a business because all other work options are either non-existent or unsatisfactory. Previous research indicated that countries with low per-capita income have high nascent entrepreneurship rates, as do countries with high per-capita income (Erkut, 2016; Gaweł, 2020). Since the emerging market of Indonesia undergoes transition to a developed country, the characteristics and motivations of millennial entrepreneurs to create entrepreneurial start-ups (whether OEA or NEA) must be well understood by policymakers so as to formulate a proper strategy for economic growth through entrepreneurship.

This article aims to highlight our understanding of the millennial entrepreneurial tendency in startup phase by observing personal characteristics, entrepreneurship characteristics, and collectivist cultural values in places of respondents' residence. We explored the following questions. Why did the participants choose to start the business? How does personality contribute to enhancing entrepreneurial business start-ups among the participants of this study? Do participants in this study possess the necessary characteristics as entrepreneurs? Finally, how are businesses practised in the cultural context of the participants places of residence?

This article contributes to the millennial entrepreneurship literature in three ways. First, it highlights the typical personality traits of millennial entrepreneurs. Second, it identifies the entrepreneurship characteristics of participants, which clarifies whether the motivation of millennial entrepreneurial is opportunity or necessity. Finally, the results will consider some western entrepreneurship theories that are applicable to Asian milieu.

This article is structured in the following way: we will begin by presenting the relevant literature for this study. We will then describe the conceptual and methodological framework, before establishing the analysis of the empirical data. For confirmation, we will use covariance base structural equation modelling (CB-SEM) with the aid of SPSS Amos software. In the final section, we will portray conclusions, limitations, and suggestion for future research.

\section{LITERATURE REVIEW}

Below, we present the literature review of research studies focused on personality, cultural value and entrepreneurial characteristics. Despite the fact that meta-analyses reveal that the Big Five personality traits (emotional stability, extraversion, openness to experience, agreeableness, and conscientiousness) forecast business aspiration, forming, and attainment (Antoncic et al., 2015), there is little concurrence about the significance of personality as a predictor of entrepreneurial success or failure (Ko- 
non \& Kritikos, 2019). This is because the debates on whether entrepreneurs are made or born continues (Viinikainen et al., 2017; López-Núñez et al., 2020). However, given that behaviour transpires in line with an individual's personality, we should believe that individual distinction in entrepreneurship is an expression of an individual's personality. Earlier studies reveal regional dissimilarity in intraindividual entrepreneurial clusters of the Big Five traits (scoring high in extraversion, conscientiousness, and openness to experience and lower in agreeableness and neuroticism), which are to be associated with more compelling geographical entrepreneurial undertakings (Audretsch et al., 2017; Obschonka et al., 2019). Broadening this rationality to entrepreneurial accomplishment, we envisage people scoring higher on personality traits associated with the entrepreneurial behaviour to be more burgeoning entrepreneurs. This is because they will be easier to capture in the expected manner, will perform that way with less sensitive endeavour or pressure, and will remain in high spirit during hard times.

Arranz et al. (2019) accentuate that commitment to be an entrepreneur among millennial generation is not only caused by personal factors but also by environmental influences such as government regulations, the country's financial and economic infrastructure, market opening, and numerous socio-cultural strands. Up till now, the Indonesian government supported entrepreneurship, although progress in the matter remains unconvincing. The authorities have initiated various actions to enhance the growth of entrepreneurship by arranging a propitious economic environment, financing, funding plans, tax deductions, and business consultation hubs. Moreover, the government has treated entrepreneurship as a fashion to accelerate the industrial configuration among the coming generation (Prasetyo \& Kristanti, 2020).

Looi (2019) affirms that an individualistic culture supports entrepreneurship for it lets an individual do and alter whatever he/she intends irrespective of whether these are organised, probing, or speculative. Further, as noticed by Bogatyreva et al. (2019) individuals turn out to be entrepreneurs since they are committed to acknowledged values conflicting with those of their former proprietors. These disputes allure them to be independent and start their own business. In contrast, Indonesia is a collectivistic society where social attachment holds a contributory mantle in several exposures of living. Similar to other South East Asian collectivist countries, business is customarily set up in the patrimonialism tone, where there prevails paternalism, echelons, dependability, mutualism, favouritism, personalism, and patronage (Rajiani \& Pypłacz, 2018).

Studies devoted to investigating the factors affecting entrepreneurship suggests that individuals with specific personality traits make their desire to venture a business. Three big five personality traits (conscientiousness, disagreeableness and emotional stability) have a direct relationship with entrepreneurship (Mahmoud et al., 2020). Individual characteristics have been associated with entrepreneurs (Matos \& Hall, 2020), and the more commonly observed and cited ones are risk-taking propensity, tolerance for ambiguity, internal locus of control, innovativeness, and independence (Embi et al., 2019; Mujahid et al., 2020; Ndofirepi, 2020). The contribution of values in entrepreneurial undertaking has received proportionately modest concern from scholars. Yet, implicitly or explicitly, the research on entrepreneurship is commonly grounded on such Western values as individualism, rivalry, material acquisition, and a strict work ethic (Erpf et al., 2020). These values are not immanent in several cultures and ethnic communities, which in turns may have insubstantial relevance, in particular, developing economies. Given this reality, understanding the implications of culturally based values for the successful creation and growth of entrepreneurial ventures becomes especially critical.

Several studies have been reported on millennial as employees in the workforce (Liu et al., 2019), but research on millennial as entrepreneurs is very scarce. From this point of view, the main aims of this work are to analyse the prevalence of personality referred as individual characteristics, cultural value and entrepreneurial characteristics on entrepreneurial intentions among Indonesian millennial and to examine if they are supporting or hindering factors when applying to entrepreneurship context. Scrutinizing individual and entrepreneur characteristics by observing which ones are more entrepreneurial than others is crucial to identify potential business leaders whose contributions in kick-starting economy. This mainly is advantageous in Indonesian economies, where the recession in the late 2020s due to Covid-19 pandemic has risen unemployment at new entry levels. Consequently, identifying prospective millennial entrepreneurs is one way towards finding solutions to reduce joblessness (Meyer 
\& Meyer, 2020). However, previous research has not investigated these two factors in their joint relationship to entrepreneurial inclination. Since most research on entrepreneurship is based on theoretical frameworks established by applying data from Western cultures, little is revealed on the relevance of these frameworks in diverse cultural settings (Erpf et al., 2020). As such, the testing of such frameworks in another location will allow us to produce cross-cultural generalisability. Notably, in this research, cultural characteristics of Banjarese Indonesia are identified based on a differentiating cue hypotheses, which may reveal selected personality and entrepreneurial characteristics as significant predictors of entrepreneurial tendency. Therefore, we assumed the following research hypotheses:

H1: Individual characteristics reflected in typical personality traits significantly influence the entrepreneurial tendency of millennial generation.

H2: Cultural value has a significant effect on the entrepreneurial tendency of millennial generation.

H3: Entrepreneurial characteristics significantly influence the entrepreneurial tendency of millennial generation.

\section{RESEARCH METHODOLOGY}

Using a quantitative method, the sample was purposively selected from 551 small business owners in Banjarmasin, born in 1980 or later, which corresponds to the age range of the millennial cohort. The proposed model is shown in Figure 1.

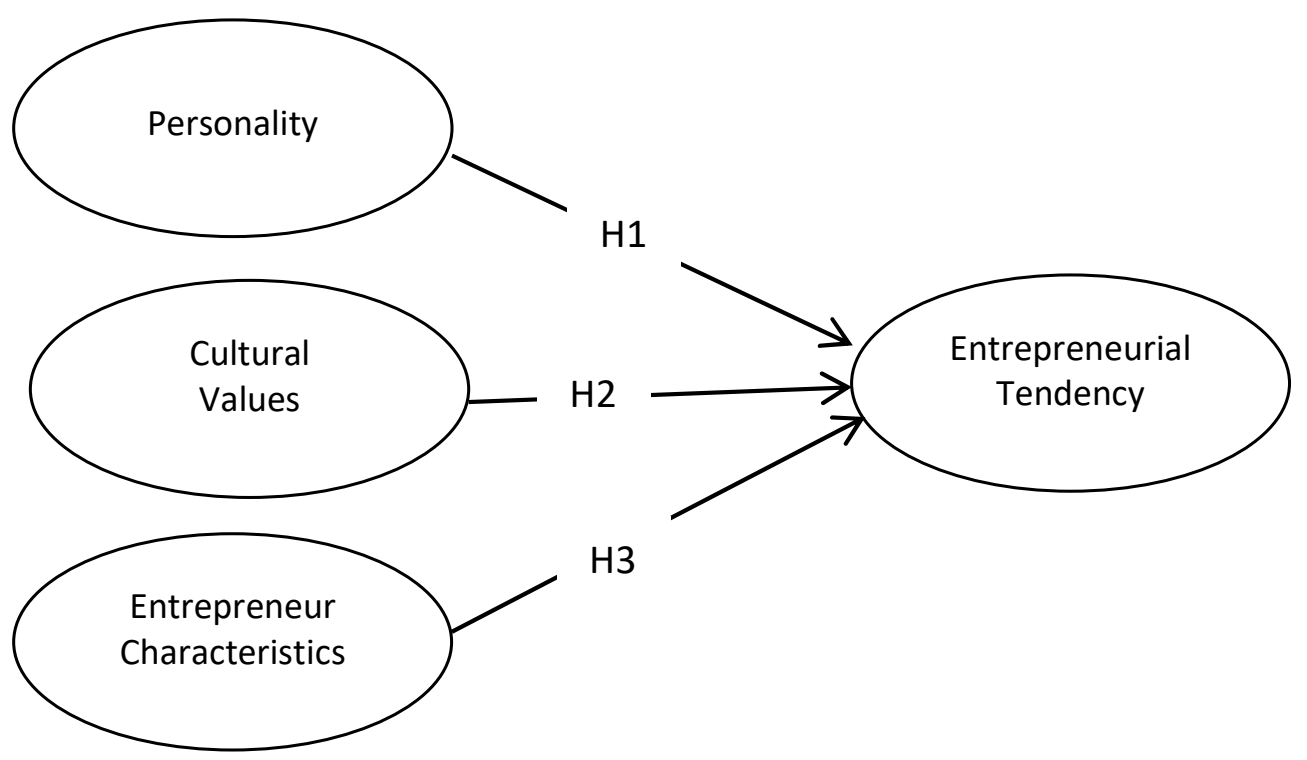

Figure 1. The proposed model of nascent millennial entrepreneurs

Source: own elaboration of Obschonka et al., 2019; Bogatyreva et al., 2019; Matos \& Hall, 2020 ; Embi et al., 2019.

Purposive sampling was employed as it is the most efficient way to study a specific domain of culture (Campbell et al., 2020), in this case mainly Banjarese people are known as devoted entrepreneurs (Rajiani et al., 2019). This research was conducted from November 2019 until May 2020 in the area of Banjarmasin City. The sample was taken based on the willingness of members who joined in a WhatsApp thread for newly established business group for millennials in South Kalimantan, Indonesia.

\section{Instrument development}

Individual characteristics were measured with brief Big Five inventories developed by Rammstedt and John (2007): the items are labelled Openness to Experience (P1), Extraversion (P2), Conscientiousness (P3), Agreeableness (P4) and Neuroticism (P5). Cultural beliefs of collectivism/individualism were estimated utilizing a six-item Hofstede's national culture insights (Minkov, 2018): the items are labelled self-interest (CV1), togetherness (CV2), group welfare (CV3), group success (CV4), individual goals 
(CV5), group loyalty (CV6). Entrepreneurial characteristics were measured by adopting the work of Mujahid et al. (2020) and Ndofirepi (2020): the items are risk-taking propensity (EC1), tolerance for ambiguity (EC2), internal locus of control (EC3), innovativeness (EC4), and independence (EC5). Entrepreneurial tendency was quantified with the Measure of Entrepreneurial Tendencies and Abilities (META), developed by Ahmetoglu et al. (2015), which has four dimensions: Entrepreneurial Proactivity (ET1; 'I am quick to spot profitable opportunities'), Entrepreneurial Creativity (ET2; 'In groups, I usually have the most innovative ideas'), Entrepreneurial Opportunism (ET3; 'I try to take advantage of every profitable opportunity I see'), and Entrepreneurial Vision (ET4; 'I want to make a difference in the world'). These items were measured on a five-point Likert scale from 'completely disagree' to 'completely agree,' while structural equation modelling with the assistance of SPSS Amos was used to examine the relationship among the items. Structural equation modelling was employed as this methodology was designed to confirm substantive theory from empirical data. In this research, theory suggests that certain personality traits do not affect other traits and that certain variables of entrepreneurial intention do not load on certain factors, so SEM was best fitted to test the theory.

What SEM includes is a series of statistical procedures allowing the assessment of causal relations among latent variables through a set of observed variables. The relationships or effects displayed in the model are justified through an appropriate comprehensive measurement. Schreiber et al. (2006) confirm that the measures enabling justification are mainly Chi-square ( $\chi 2)$, the Minimum Sample Discrepancy Function ( $\chi 2$ /df), the Goodness-of-Fit Index (GFI), the Adjusted Goodness-of-Fit Index (AGFI), the Comparative Fit Index (CFI), and the Root Mean Square Error of Approximation (RMSEA). Factors loading are estimated to ascertain discriminant validity by retaining factors loading of 0.50 or higher in the model (Hair et al., 2020). Cronbach's alpha coefficient was examined to determine reliability, which had to exceed 0.60 (Bonett \& Wright, 2015).

However, self-report questionnaires were susceptible to social desirability bias - a tendency of respondents to answer in a more socially tolerable way. To mitigate the problem, Podsakoff et al. (2012) recommend the following steps: $(a)$ detect one or more likely sources of method bias, $(b)$ manipulate them in the design of the study, and $(c)$ test if the hypothesised estimates of the relationships among the constructs generalise across conditions. Sources of method bias are detected by observing the most extreme responses (MRS), which are items with the highest loading factor in confirmatory factor analysis (Mishra, 2016). Those items are excluded, and the model is recalculated. When the result displays no significant change in $\chi 2, \chi 2 / d f, G F I, A G F I, C F I$ and RMSEA, then it is concluded that there is no social desirability bias.

\section{RESULTS AND DISCUSSION}

Respondent' demographic profiles related to gender, age, education, and length in current business are presented in Table 1. Most respondents were male (72.5\%), with the majority (52.1\%) of respondents being under 30 years old. Furthermore, most respondents received higher education, mostly at college level $(45.7 \%)$, followed by partly college level $(26.3 \%)$, and surprisingly 10 respondents $(1.8 \%)$ possess graduate degrees. At the level of junior high school, the majority of respondents (18.9\%) were in vocational/technical schools. Most start-ups are relatively new as the majority of respondents $(56.6 \%)$ has started their business in less than a year, followed with those who started the business one to two years ago (25.8\%). Only 5 respondents $(0.9 \%)$ kept their business going for more than five years.

The mean of each variable is presented in Table 2. The mean score of respondents' personality equals 14.02 (out of 10-18), as this research considered the mix of higher values of Extraversion, Conscientiousness, and Openness to Experience and lower values of Agreeableness and Neuroticism, which were acknowledged as entrepreneurs' personality across the region. The mean score of cultural value of 27 (out of 14-40) indicated the tendency of respondents towards collectivist types, in which business are set with a patrimonialist tendency. The mean score for entrepreneurial characteristics was 10 (out of 8-12), which denoted the low prevalence of these specific characteristics of entrepre- 
neurs among Banjarese Indonesia millennial generation. The mean score for the entrepreneurial tendency of 18 (out of 10-26) indicated the mild direction of the millennial generation in this area to become entrepreneurs.

Table 1. Respondent' profiles

\begin{tabular}{|c|c|c|}
\hline Basic characteristics & $\mathbf{N}$ & $\%$ \\
\hline $\begin{array}{l}\text { Gender } \\
\text { Male } \\
\text { Female } \\
\text { Total }\end{array}$ & $\begin{array}{l}400 \\
151 \\
551\end{array}$ & $\begin{array}{l}72.5 \\
27.5 \\
100\end{array}$ \\
\hline $\begin{array}{l}\text { Ages } \\
>40 \\
35-40 \\
30-34 \\
<30\end{array}$ & $\begin{array}{c}10 \\
92 \\
162 \\
287 \\
\end{array}$ & $\begin{array}{c}1.8 \\
16.7 \\
29.4 \\
52.1\end{array}$ \\
\hline Total & 551 & 100 \\
\hline $\begin{array}{l}\text { Education } \\
\text { High School } \\
\text { Vocational/technical } \\
\text { Some college } \\
\text { College } \\
\text { Graduate } \\
\text { Total }\end{array}$ & $\begin{array}{c}40 \\
104 \\
145 \\
252 \\
10 \\
551\end{array}$ & $\begin{array}{r}7.3 \\
18.9 \\
26.3 \\
45.7 \\
1.8 \\
100\end{array}$ \\
\hline $\begin{array}{l}\text { Current business duration } \\
>5 \text { years } \\
3-4 \text { years } \\
1-2 \text { years } \\
<1 \text { year } \\
\text { Total }\end{array}$ & $\begin{array}{c}5 \\
92 \\
142 \\
312 \\
551\end{array}$ & $\begin{array}{c}0.9 \\
16.7 \\
25.8 \\
56.6 \\
100\end{array}$ \\
\hline
\end{tabular}

Source: own study.

Table 2. Descriptive statistics for variables

\begin{tabular}{|l|c|c|c|c|c|}
\hline \multicolumn{1}{|c|}{ Variables } & N & Minimum & Maximum & Mean & Std. Deviation \\
\hline Personality & 551 & 10.00 & 20.00 & 15 & 1.833 \\
\hline Cultural Value & 551 & 14.00 & 40.00 & 27.00 & 4.413 \\
\hline Entrepreneurial Characteristics & 551 & 8.00 & 12.00 & 10 & 2.660 \\
\hline Entrepreneurial Tendency & 551 & 10.00 & 26.00 & 18.00 & 1.436 \\
\hline
\end{tabular}

Source: own elaboration based on SEM calculation.

Measurement model in Table 3 evidences that the loading factors are above 0.50, which means that the convergent validity of the instrument is satisfactory. Moreover, Table 3 displays the result of Cronbach's alpha coefficients for the instrument to surpass 0.60 , which is the threshold for accepted reliability.

The full specified model of the research is depicted in Figure 2. What SEM demands is for small value of Chi-square statistic $(\mathrm{X} 2)$ and probability $(\mathrm{P})$ to be smaller than 0.05 . Although these statistics are usually conveyed in SEM results, they are rarely considered and generally go unnoticed as researchers prefer alternative measurements to evaluate model fit (Alavi et al., 2020).

The justification was that Chi-square statistic $\left(\chi_{2}\right)$ and probability $(P)$ were strictly connected to sample size, which meant that the bigger the sample, the smaller the Chi-square statistic and the higher the probability. Hu and Bentler (1999) contend that limits approximate to 0.95 for the TuckerLewis Index (TLI), 0.90 for the Norm Fit Index (NFI), 0.90 for the Incremental Fit Index (IFI), and 0.06 for the Root Mean Square Error of Approximation (RMSEA), which sufficiently substantiated the acceptance of a precise fit between our suggested model and data. Other researchers suggest other goodness-of-fit statistics to contain the Minimum Sample Discrepancy Function (CMIN/DF) expected 
at $\leq 2.0$ (Arbuckle, 2011), the Goodness-of-Fit Index (GFI) approaching 0.90, and the Adjusted Goodness-of-Fit Index (AGFI) close to 0.90 or higher (Hair et al., 2020). By referring to the tests of $\chi 2(\chi 2=$ $10.932)$, probability $(P=0.10)$, and GFI $(0.796)$, our model cannot represent goodness-of-fit. However, other measurement showed that the model demonstrated permissible robustness in CMIN/DF $=1.203$ (expected smaller than 2), AGFI $=0.988$ (higher than 0.90), $\mathrm{CFI}=1$ (higher than 0.95), $\mathrm{TLI}=0.983$ (higher than 0.95), and RMSEA $=0.09$ (higher than 0.06).

Table 3. Validity and reliability

\begin{tabular}{|l|c|c|}
\hline \multicolumn{1}{|c|}{ Construct } & Loading Factors & Cronbach Alpha \\
\hline P1<---Individual Characteristics & 0.673 & 0.831 \\
P2<--- Individual Characteristics & 0.797 & 0.765 \\
P3<--- Individual Characteristics & 0.601 & 0.783 \\
P4<--- Individual Characteristics & 0.785 & 0.770 \\
P5<--- Individual Characteristics & 0.651 & 0.762 \\
\hline CV1<---Cultural Value & 0.631 & 0.821 \\
CV2<---Cultural Value & 0.625 & 0.803 \\
CV3<---Cultural Value & 0.732 & 0.783 \\
CV4<---Cultural Value & 0.721 & 0.815 \\
CV5<---Cultural Value & 0.811 & 0.792 \\
CV6<---Cultural Value & 0.802 & 0.722 \\
\hline EC1 <---Entrepreneurial Characteristics & 0.716 & 0.675 \\
EC2 <---Entrepreneurial Characteristics & 0.642 & 0.702 \\
EC3<---Entrepreneurial Characteristics & 0.725 & 0.753 \\
EC4<---Entrepreneurial Characteristics & 0.753 & 0.776 \\
EC5 <---Entrepreneurial Characteristics & 0.730 & 0.751 \\
\hline ET1 <---Entrepreneurial Tendency & & 0.826 \\
ET2<---Entrepreneurial Tendency & 0.784 & 0.811 \\
ET3<---Entrepreneurial Tendency & 0.721 & 0.793 \\
ET4<---Entrepreneurial Tendency & 0.710 & 0.817 \\
\hline
\end{tabular}

Source: own elaboration based on SEM calculation.

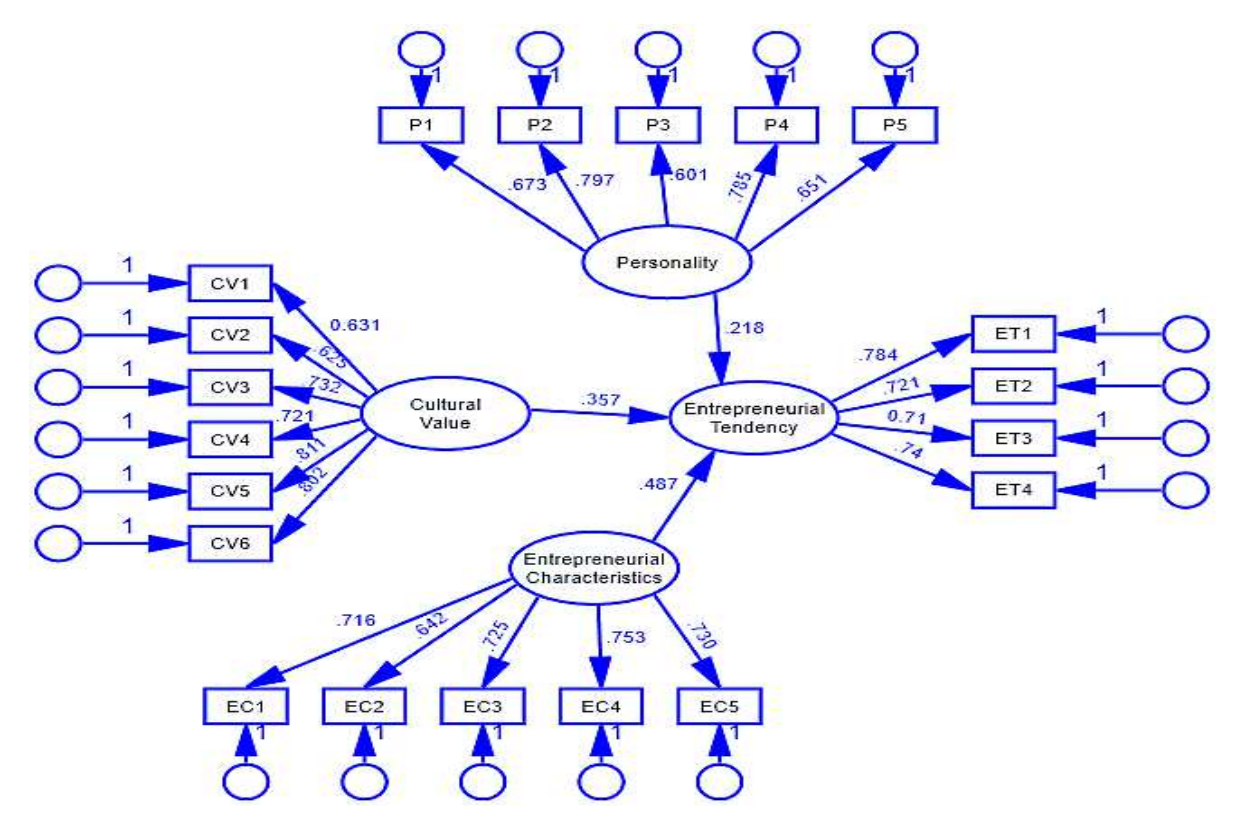

Figure 2. Full model after specification

Note: Measure of fit: RMSEA $=0.091, \mathrm{GFI}=0.796, \mathrm{AGFI}=0.988, \mathrm{CFI}=1, \mathrm{TLI}=0.983$,

Chi Squared $=15,763$, Chi Squared $/ D F=1.203$, P-value $=0.235$

Source: own elaboration based on SEM calculation. 
Most extreme responses (MRS) were identified in four items: (a) 'I have few artistic interests,' (b) 'I am generally trusting,' (c) 'group success is more important than individual success,' and (d) 'individuals should only pursue their goals after considering the welfare of the group.' However, after re-calculating the model without these four items, the measure of the fit result remained the same, thus indicating that there is no bias of tendency from respondents to answer the questions in a much more socially acceptable way.

The summary result of structural equation modelling is exhibited in Table 4, which demonstrates that all three hypotheses are accepted.

Table 4. The summary of estimated models

\begin{tabular}{|l|c|c|c|c|c|}
\hline \multicolumn{1}{|c|}{ Construct } & Estimate & SE & CR & P & Conclusion \\
\hline $\begin{array}{l}\text { Personality -- > } \\
\text { Entrepreneurial Tendency }\end{array}$ & 0.218 & 0.184 & 2.410 & 0.005 & Significant \\
\hline $\begin{array}{l}\text { Cultural Value -- > } \\
\text { Entrepreneurial Tendency }\end{array}$ & 0.357 & 0.095 & 2.631 & 0.002 & Significant \\
\hline $\begin{array}{l}\text { Entrepreneurial Characteristics -- > } \\
\text { Entrepreneurial Tendency }\end{array}$ & 0.487 & 0.162 & 3.511 & 0.001 & Significant \\
\hline
\end{tabular}

Source: own calculations based on SEM.

The findings supported the notion from developed countries that Big Five traits are related to greater regional entrepreneurial achievement (Audretsch et al., 2017; Obschonka et al., 2019). Although the results revealed that the variable of entrepreneurial characteristics was the most dominant in determining the entrepreneurial tendency, the mean for this variable was the lowest. This confirms the finding that research on entrepreneurship often follows Western individualism values, which are not pervasive in collectivist cultures and ethnic communities like Banjarese Indonesia. Thus, we highlighted the entrepreneurial characteristics in terms of risk-taking propensity, tolerance for ambiguity, locus of control, innovativeness, and independence, which are also found low in a separate study conducted in another province of Indonesia (Herlinawati et al., 2019).

Entrepreneurs are widely credited for resisting more instability, in reality, they are the only ones accountable for their decisions. Li and Ahlstrom (2019) argue that a conceivable motive for the higher risk-taking behaviour stems from entrepreneurs' preference to view business circumstances with more certainty than others and recognise them as "opportunities," while non-entrepreneurs may perceive little possibility in the same circumstances. Therefore, the entrepreneurs can easier accept these "opportunities" compared to less entrepreneurial individuals. Among the South East Asians, risk-taking propensity is not common. Hofstede (2015) reassures that South East Asians, including Indonesians, generally circumvent uncertainty and prefer security. What is natural for Indonesian culture is uncertainty avoidance as it inclines to create anticipated behaviour and does not stand rules violation. The Indonesians practise harmony, distinctive in Indonesian relationships, to minimise risk among individuals. Therefore, the risk-taking propensity is a distinguishing prompt because it is not a typical characteristic among Indonesians. An individual willing to risk and stand firm in the face of uncertainty is more likely to have an entrepreneurial zest compared to the one who avoids from uncertainty. Thus, low risk-taking propensity impedes Indonesian millennial generation to become entrepreneurs.

Entrepreneurs experience an ambiguity that is triggered by the vibrant business world. Besides stumbling blocks and astonishments, an entrepreneurial setting is usually deprived of organisation, structure, and order. Nevertheless, entrepreneurs flourish in ambivalent circumstances. Therefore, entrepreneurs are acknowledged for having a higher tolerance for ambiguity and relish a state of affairs with the absence of structure and procedures (van de Sandt \& Mauer, 2019). Similar to risk-taking propensity, the low tolerance of ambiguity hinders Indonesian millennial generation from producing entrepreneurs.

Entrepreneurs commonly show a high internal locus of control (Asante \& Affum-Osei, 2019): a belief that they control their own life's events. Thus, when there is a catastrophe, they ascribe them to own conduct (Charoensukmongkol, 2019). In Banjarese Indonesian culture, Islam is a fundamental element in ethnic recognition. All Banjarese Indonesian are Muslim and endorse Islam as the way of life. 
Consequently, Islam pervades whole aspects of experience in the realm of values and behaviours (Rajiani et al., 2019). In Islam teachings, the divine law is inflexible and irrevocable; it is hard to find any Banjarese Indonesian go against the absolute value written in the Quran. The ensuing philosophy of takdir is the belief that destiny or supernatural power dictates individual aftermath, which is extensively validated. Therefore, given Indonesian's wide-ranging confidence in an external rather than internal locus of control, many estimate that individuals who favour control over their own lives are rarely found among Indonesians. Therefore, the external locus of control hampers the Indonesian millennial generation to produce entrepreneur.

Because entrepreneurs incline to be separated from what is mundane and regular, they frequently initiate new ideas and are more innovative (Mazzarol \& Reboud, 2020). Their tolerance towards making mistakes further assists them in solving creativity obstructions (Danish et al., 2019). However, Indonesians are not acknowledged for business innovativeness (Rajiani \& Kot, 2018). One reason for that is the paternalistic setting: a well-defined hierarchy, with its explicit roles for each member (Hofstede, 2015), that inhibits creativity and innovation (Lee et al., 2019).

Furthermore, an essential concept to Indonesians is face, which is a measure of social value. The potential loss of face from failure discourages innovativeness. Therefore, in a culture that does not encourage innovativeness, it becomes a differentiating cue that distinguishes entrepreneurial spirit among specific individuals. Thus, innovativeness hampers the Indonesian millennial generation to produce entrepreneurs.

Moreover, entrepreneurs tend to be self-reliant and independent (Kennedy et al., 2020) for they must be able to work on their own and need less social support than non-entrepreneurs. Within the Indonesian setting, dependence on the superior is reflected in the adage "asal bapak senang" - which means "keep fathers happy" - a tendency in which people please the boss for the sake of saving their socio-economic positions (Dick, 2019). Bapak means father, but it can also mean a charismatic figure that cares for community members in exchange for loyalty. Given the relationship between independence and entrepreneurship, we expect such independence to be a predictor of entrepreneurial spirit. Thus, dependence hampers the Indonesian millennial generation to produce entrepreneurs.

Summarising, although Indonesian millennial entrepreneurs from the samples in this research run their business, entrepreneurship is not in their hearts and minds. As nascent entrepreneurs, they pursue an opportunity, i.e. a prospect to introduce new products or services, serve new markets, or develop more efficient production methods in a profitable manner or opportunistic behaviours (Rahman et al., 2020). However, before such a venture is practically proven, the opportunity is just a venture idea. In other words, the option they follow is still only perceptual, bolstered by the nascent entrepreneur's personal beliefs about the viability of venturing, which yields to the nascent entrepreneur attempts to achieve success (Busch \& Barkema, 2020).

Our findings support Zamrudi and Yulianti (2020) research to identify millennial entrepreneurs among Indonesian university students and reveal the existence of low self-efficacy among the respondents. Initially defined by Bandura (1977) as a belief in one's ability to fulfil actions, self-efficacy can influence one's cognition, self-confidence, courses of action, and perceptions of control. Thus, selfefficacy has become a crucial predictor of success, with higher levels of self-efficacy supporting perseverance and goal achievement in newly established business (Margahana, 2019). Similar to other nascent entrepreneurs, the Indonesian millennial entrepreneur pursues opportunities; these opportunities are uncertain, and not all of these pursuits result in operating businesses. Without characteristics of an entrepreneur, their failure - like that of other nascent entrepreneurs in different regions of Indonesia (Herlinawati et al., 2019; Anggadwita \& Palalić, 2020) - can be easily attributed to naïvely pursuing an unfeasible or inoperable opportunity. Indonesian millennial entrepreneurs with sufficient conviction about merits of the pursued opportunity can feel compelled to persist in their venturing efforts towards venture emergence. However, most importantly, their equally skilled counterparts who lose confidence in the opportunity may choose to abandon their goals. 


\section{Managerial implications}

In light of the economic recession during the Covid-19 pandemic, the cultivating of millennial entrepreneurs to boost the economy is even more precarious. The government may use the crisis as a chance to start new businesses. Still, prospective entrepreneurs should be motivated to take matters into their hands by moulding internal locus of control and not let external motives dictate their actions. Furthermore, rewards to businesses in times of recovery should be accentuated by monetary and security motivations. This is also applicable to the recruiting and training of millennial employees in an entrepreneurial atmosphere. Selection tests grounded on risk-taking propensity and internal locus of control can be used to classify employees better matched to work in an entrepreneurial setting. Such employees can be organised to perform tasks that require entrepreneurial abilities. On the other hand, millennial employees who score average in this characteristic can be assigned to tasks that do not require risk-taking. The matching of task criteria to personality will confirm that the right person is selected for the right job. Moreover, training on how to take more deliberate risks and set internal locus of control can be introduced to cultivate an entrepreneurial spirit among millennial employees.

\section{CONCLUSIONS}

The Indonesian millennial generation displays little enthusiasm for entrepreneurship compared to previous generations. This low entrepreneurial activity may be attributed to limited real business exposure, given their young age, and delayed career start that results from the trend to pursue a higher education degree. However, millennials may become an excellent entrepreneurial generation because of their perspicacity as digital citizens in the era of technology-governed business. Given the unique social and historical conditions forming this generational cohort in Indonesia, we must rework presentday Indonesian cultural values as a point of reference for future study in the country.

Empirical insight into western entrepreneurship theory indicates that Indonesian's ability to fit into this framework is problematical. Thus, we may still need to wait a long time before we witness new affluent millennial entrepreneurs from this region. Nevertheless, Indonesia can learn from western entrepreneurship framework by decisively analysing their prospective benefits and unfavourable outcomes and selectively applying only those elements that are applicable to Indonesian society.

One limitation of our research is that we employed a purposive sampling technique strategy to collect information among newly established businesses owned by millennial entrepreneurs, which may have affected the generalisability of outcomes. Another limitation is that cross-sectional quantitative examinations inhibited our ability to reveal comprehensive answers to questions: "why do some people recognise opportunities while others do not?" and "why do some try to develop such opportunities while others do not?".

Future research should examine particular cultural variables that comprise the non-compatibility of Western ideas in the Asian context. Besides the cultural variables of collectivism investigated in the current study, future research should explore high versus low uncertainty avoidance, e.g. in a society with individuals not concerned about risks in the current business affairs - as they are more comfortable with ambiguity and uncertainty (low uncertainty avoidance) - entrepreneurship cannot be incorporated more than in a society with high uncertainty avoidance.

\section{REFERENCES}

Ahmetoglu, G., Harding, X., Akhtar, R., \& Chamorro-Premuzic, T. (2015). Predictors of creative achievement: Assessing the impact of entrepreneurial potential, perfectionism, and employee engagement. Creativity Research Journal, 27(2), 198-205. https://doi.org/10.1080/10400419.2015.1030293

Alavi, M., Visentin, D.C., Thapa, D.K., Hunt, G.E., Watson, R., \& Cleary, M. (2020). Chi-square for model fit in confirmatory factor analysis. Journal of Advanced Nursing, 76, 2209-2211. https://doi.org/10.1111/jan.14399 
Anggadwita, G., \& Palalić, R. (2020). Entrepreneurship in Indonesia: some contextual aspects. In Research Handbook on Entrepreneurship in Emerging Economies. Edward Elgar Publishing. https://doi.org/10.4337/9781788973717

Antoncic, B., Bratkovic Kregar, T., Singh, G., \& DeNoble, A.F. (2015). The big five personality-entrepreneurship relationship: Evidence from Slovenia. Journal of Small Business Management, 53(3), 819-841. https://doi.org/10.1111/jsbm.12089

Arbuckle, J.L. (2011). IBM SPSS Amos 20 user's guide. Amos Development Corporation, SPSS Inc. Retrieved from $\mathrm{ftp}: / / 129.35 .224 .15 /$ software/analytics/spss/documentation/amos/20.0/en/Manuals/IBM_SPSS_Amos_User_Guide.pdf on July 19, 2020.

Arranz, N., Arroyabe, M.F., \& Fdez. de Arroyabe, J.C. (2019). Entrepreneurial intention and obstacles of undergraduate students: the case of the universities of Andalusia. Studies in Higher Education, 44(11), 2011-2024. https://doi.org/10.1080/03075079.2018.1486812

Asante, E.A., \& Affum-Osei, E. (2019). Entrepreneurship as a career choice: The impact of locus of control on aspiring entrepreneurs' opportunity recognition. Journal of Business Research, 98, 227-235. https://doi.org/10.1016/j.jbusres.2019.02.006

Audretsch, D.B., Obschonka, M., Gosling, S.D., \& Potter, J. (2017). A new perspective on entrepreneurial regions: linking cultural identity with latent and manifest entrepreneurship. Small Business Economics, 48(3), 681697. https://doi.org/10.1007/s11187-016-9787-9

Bandura, A. (1977). Self-efficacy: toward a unifying theory of behavioral change. Psychological Review, 84(2), 191. Retrieved from https://psycnet.apa.org/doi/10.1037/0033-295X.84.2.191 on July 29, 2020.

BBC News (2019). Millennials-China's new revolution. BBC January 12, 2019 . Retrieved from https://archive.org/details/BBCNEWS on May 25, 2020.

Bogatyreva, K., Edelman, L.F., Manolova, T.S., Osiyevskyy, O., \& Shirokova, G. (2019). When do entrepreneurial intentions lead to actions? The role of national culture. Journal of Business Research, 96, 309-321. https://doi.org/10.1016/j.jbusres.2018.11.034

Bonett, D.G., \& Wright, T.A. (2015). Cronbach's alpha reliability: Interval estimation, hypothesis testing, and sample size planning. Journal of Organizational Behavior, 36(1), 3-15. https://doi.org/10.1002/job.1960

Busch, C., \& Barkema, H. (2020). Planned Luck: How Incubators Can Facilitate Serendipity for Nascent Entrepreneurs Through Fostering Network Embeddedness. Entrepreneurship Theory and Practice, 1042258720915798. https://doi.org/10.1177/1042258720915798

Campbell, S., Greenwood, M., Prior, S., Shearer, T., Walkem, K., Young, S., \& Walker, K. (2020). Purposive sampling: complex or simple? Research case examples. Journal of Research in Nursing, 1744987120927206. https://doi.org/10.1177/1744987120927206

Chadha, S., \& Dutta, N. (2020). Linking entrepreneurship, innovation and economic growth: evidence from GEM countries. International Journal of Technoentrepreneurship, 4(1), 22-31. https://doi.org/10.1504/IJTE.2020.108032

Chansuchai, P. (2019). The value-added product of community enterprise according to sufficiency economy toward sustainable development of entrepreneurs. Polish Journal of Management Studies, 20(2), 174-185. https://doi.org/10.17512/pjms.2019.20.2.15

Charoensukmongkol, P. (2019). Moderating roles of external locus of control and knowledge expertise on the relationship between superstitious belief and stock trading performance. Kasetsart Journal of Social Sciences, 40(1), 47-54. Retrieved from https://so04.tci-thaijo.org/index.php/kjss/article/view/235322 on February $11,2020$.

Covin, J.G., Rigtering, J.C., Hughes, M., Kraus, S., Cheng, C.F., \& Bouncken, R.B. (2020). Individual and team entrepreneurial orientation: Scale development and configurations for success. Journal of Business Research, 112, 1-12. https://doi.org/10.1016/j.jbusres.2020.02.023

Danish, R.Q., Asghar, J., Ahmad, Z., \& Ali, H.F. (2019). Factors affecting "entrepreneurial culture": the mediating role of creativity. Journal of Innovation and Entrepreneurship, 8(1), 1-12. https://doi.org/10.1186/s13731-019-0108-9

Dick, H. (2019). The Indonesian Economy in Transition: Policy Challenges in the Jokowi Era and Beyond. Bulletin of Indonesian Economic Studies, 55(2), 259-262. https://doi.org/10.1080/00074918.2019.1639246 
Duan, J., Yin, J., Xu, Y., \& Wu, D. (2020). Should I stay or should I go? Job demands' push and entrepreneurial resources' pull in Chinese migrant workers' return-home entrepreneurial intention. Entrepreneurship \& Regional Development, 32(5-6), 429-448. https://doi.org/10.1080/08985626.2019.1640455

Embi, N.A.C., Jaiyeoba, H.B., \& Yussof, S.A. (2019). The effects of students' entrepreneurial characteristics on their propensity to become entrepreneurs in Malaysia. Education and Training, 61(7-8), 1020-1037. https://doi.org/10.1108/ET-11-2018-0229

Erkut, B. (2016). Entrepreneurship and Economic Freedom: Do Objective and Subjective Data Reflect the Same Tendencies?. Entrepreneurial Business and Economics Review, 4(3), 11-26. https://doi.org/10.15678/EBER.2016.040302

Erpf, P., Butkevičienè, E., \& Pučètaitè, R. (2020). Between de Jure and de Facto: Embedding Western Concepts of Social Entrepreneurship in Post-Socialist Reality. Journal of Social Entrepreneurship, 1-28. https://doi.org/10.1080/19420676.2020.1751245

Freiling, J., \& Harima, J. (2019). Entrepreneurial Finance. In Entrepreneurship (pp. 295-340). Wiesbaden: Springer Gabler. https://doi.org/10.1007/978-3-658-26117-7_14

Gaweł, A. (2020). Does Entrepreneurship Affect Income Inequality within Countries? Direct and Indirect Effects in European Countries. Entrepreneurial Business and Economics Review, 8(2), 93-110. https://doi.org/10.15678/EBER.2020.080205

Hair Jr, J.F., Howard, M.C., \& Nitzl, C. (2020). Assessing measurement model quality in PLS-SEM using confirmatory composite analysis. Journal of Business Research, 109, 101-110. https://doi.org/10.1016/j.jbusres.2019.11.069

He, H., Bai, Y., \& Xiao, X. (2020). How Past Failure Predicts Subsequent Entrepreneurial Intention: A Comparative Study of Mainland China and Taiwan. Sustainability, 12(6), 2331. https://doi.org/10.3390/su12062331

Herlinawati, E., Ahman, E., \& Machmud, A. (2019). The Effect of Entrepreneurial Orientation on SMEs Business Performance in Indonesia. Journal of Entrepreneurship Education, 22(5), 1-15. Retrieved from https://www.questia.com/library/journal/1P4-2331772335/the-effect-of-entrepreneurial-orientation-onsmes on June 10, 2020.

Hofstede, G.J. (2015). Culture's causes: the next challenge. Cross Cultural Management, 22(4), 545-569. https://doi.org/10.1108/CCM-03-2015-0040

Hu, L.T., \& Bentler, P.M. (1999). Cutoff criteria for fit indexes in covariance structure analysis: Conventional criteria versus new alternatives. Structural Equation Modeling: a Multidisciplinary Journal, 6(1), 1-55. Retrieved from https://www.tandfonline.com/doi/abs/10.1080/10705519909540118 on March 10, 2020.

Kennedy, E.D., McMahon, S.R., \& Reis, D. (2020). Independence in the Making: Using Makerspace Experiences to Build Foundational Entrepreneurial Competencies. Entrepreneurship Education and Pedagogy, 2515127420946036. https://doi.org/10.1177/2515127420946036

Konon, A., \& Kritikos, A.S. (2019). Prediction based on entrepreneurship-prone personality profiles: sometimes worse than the toss of a coin. Small Business Economics, 53(1), 1-20. https://doi.org/10.1007/s11187-018-0111-8

Lee, C., Hallak, R., \& Sardeshmukh, S.R. (2019). Creativity and innovation in the restaurant sector: Supply-side processes and barriers to implementation. Tourism Management Perspectives, 31, 54-62. https://doi.org/10.1016/j.tmp.2019.03.011

Li, Y., \& Ahlstrom, D. (2019). Risk-taking in entrepreneurial decision-making: A dynamic model of venture decision. Asia Pacific Journal of Management, 1-35. https://doi.org/10.1007/s10490-018-9631-7

Liu, J., Zhu, Y., Serapio, M.G., \& Cavusgil, S.T. (2019). The new generation of millennial entrepreneurs: A review and call for research. International Business Review, 28(5), 101581. https://doi.org/10.1016/j.ibusrev.2019.05.001

Looi, K.H. (2019). Undergraduates' motivations for entrepreneurial intentions: the role of individualistic values and ethnicity. Journal of Education and Work, 32(5), 465-483. https://doi.org/10.1080/13639080.2019.1640866

López-Núñez, M.I., Rubio-Valdehita, S., Aparicio-García, M.E., \& Díaz-Ramiro, E.M. (2020). Are entrepreneurs born or made? The influence of personality. Personality and Individual Differences, 154, 109699. https://doi.org/10.1016/j.paid.2019.109699

Makszin, K., Medve-Bálint, G.E.R.G.Ő., \& Bohle, D. (2020). 17 North and South, East and West: Is it Possible to Bridge the Gap?. Governance and Politics in the Post-Crisis European Union, 335. Retrieved from https://books.google.co.id/books?hl=en\&lr=\&id=noLoDwAAQBAJ\&oi=fnd\&pg=PA335\&ots=f43_okFill\&sig=t35ZbX3TPWgMQsDHlaGB3NkFLUE\&redir_esc=y\#v=onepage\&q\&f=false on September 15, 2020. 
Mahmoud, M.A., Ahmad, S., \& Poespowidjojo, D.A.L. (2020). Intrapreneurial behavior, big five personality and individual performance. Management Research Review. https://doi.org/10.1108/MRR-09-2019-0419

Margahana, H. (2019). Self-Efficacy, Self-Personality And Self Confidence On Entrepreneurial Intention: Study On Young Enterprises. Journal of Entrepreneurship Education, 22(1), 1-12. Retrieved from https://www.questia.com/library/journal/1P4-2238484854/self-efficacy-self-personality-and-self-confidence on March 10, 2020.

Matos, S., \& Hall, J. (2020). An exploratory study of entrepreneurs in impoverished communities: when institutional factors and individual characteristics result in non-productive entrepreneurship. Entrepreneurship \& Regional Development, 32(1-2), 134-155. https://doi.org/10.1080/08985626.2019.1640476

Mazzarol, T., \& Reboud, S. (2020). The Entrepreneur. In T.W. Mazzarol \& S. Reboud (Eds.) Entrepreneurship and Innovation (pp. 35-61). Singapore: Springer. https://doi.org/10.1007/978-981-13-9412-6_2

Meyer, N., \& Meyer, D.F. (2020). Entrepreneurship as a Predictive Factor for Employment and Investment: the Case of Selected European Countries. EuroEconomica, 39(2). Retrieved from http://dj.univ-danubius.ro/index.php/EE/article/view/300 on October 10, 2020.

Mishra, M. (2016). Confirmatory Factor Analysis (CFA) as an Analytical Technique to Assess Measurement Error in Survey Research: A Review. Paradigm, 20(2), 97-112. https://doi.org/10.1177/0971890716672933

Minkov, M. (2018). A revision of Hofstede's model of national culture: Old evidence and new data from 56 countries. Cross Cultural \& Strategic Management, 25(2), 231-256. https://doi.org/10.1108/CCSM-03-2017-0033

Mujahid, S., Mubarik, M.S., \& Naghavi, N. (2020). Developing entrepreneurial intentions: what matters?. Middle East Journal of Management, 7(1), 41-59. https://doi.org/10.1504/MEJM.2020.105225

Ndofirepi, T.M. (2020). Relationship between entrepreneurship education and entrepreneurial goal intentions: psychological traits as mediators. Journal of Innovation and Entrepreneurship, 9(1), 1-20. https://doi.org/10.1186/s13731-020-0115-x

Obschonka, M., Moeller, J., \& Goethner, M. (2019). Entrepreneurial passion and personality: the case of academic entrepreneurship. Frontiers in Psychology, 9, (2697), 1-15. https://doi.org/10.1186/s13731-020-0115-x

Podsakoff, P.M., Mackenzie, S.B., \& Podsakoff, N.P. (2012). Sources of method bias in social science research and recommendations on how to control it. Annual Review of Psychology, 63, 539-569. https://doi.org/10.1146/annurev-psych-120710-100452

Prasetyo, P.E., \& Kistanti, N.R. (2020). Human capital, institutional economics and entrepreneurship as a driver for quality \& sustainable economic growth. Entrepreneurship and Sustainability Issues, 7(4), 2575-2589. https://doi.org/10.9770/jesi.2020.7.4(1)

Rahman, H., Besra, E., \& Nurhayati (2020). Explicating failure among nascent entrepreneurs in West Sumatra: The nexus of psycho-economic factors and opportunistic behavior. Journal of Entrepreneurship, Management and Innovation, 16(2), 37-66. Retrieved from https://ww.jemi.edu.pl/vol-16-issue-2-2020/explicatingfailure-among-nascent-entrepreneurs-in-west-sumatra-the-nexus-of-psycho-economic-factors-and-opportunistic-behavior on August 10, 2020.

Rajiani, I., \& Pypłacz, P. (2018). National culture as modality in managing the carbon economy in Southeast Asia. Polish Journal of Management Studies, 18(1), 296-310. https://doi.org/10.17512/pjms.2018.18.1.22

Rajiani, I., \& Kot, S. (2018). The prospective consumers of the Indonesian green aviation initiative for sustainable development in air transportation. Sustainability, 10(6), 1772. https://doi.org/10.3390/su10061772

Rajiani, I., Hadi, S., \& Abbas, E.W. (2019). The value in banjarese culture through the thought of a prominent ulema as a model of developing entrepreneurship based religion. In Proceedings of the 33rd International Business Information Management Association Conference, IBIMA 2019: Education Excellence and Innovation Management through Vision 2020 (pp. 258-264). International Business Information Management Association, IBIMA. Retrieved from https://www.scopus.com/record/display.uri?eid=2-s2.085074099450\&origin=inward\&txGid=bc24d2e36f37e0c892156993e48fe5ec on March 10, 2020.

Rammstedt, B., \& John, O.P. (2007). Measuring personality in one minute or less: A 10-item short version of the Big Five Inventory in English and German. Journal of Research in Personality, 41(1), $203-212$. https://doi.org/10.1016/j.jrp.2006.02.001

Rauch, J. (2018). Generation Next-Millennials will outnumber baby-boomers in 2019. The Economist The World in 2019 special issue, November 7, 2019. Retrieved from https://worldin2019.economist.com/millennialsvboomers on June 20, 2020. 
Schreiber, J.B., Nora, A., Stage, F.K., Barlow, E.A., \& King, J. (2006). Reporting structural equation modeling and confirmatory factor analysis results: a review. The Journal of Educational Research, 99(6), 323-337. https://doi.org/10.3200/JOER.99.6.323-338

van de Sandt, N., \& Mauer, R. (2019). The effects of action-based entrepreneurship education on ambiguity tolerance and entrepreneurial alertness. Journal of Entrepreneurship Education, 22(4), 1-12. Retrieved from https://search.proquest.com/openview/18bc2fbd382f6ef07717e04c4216d557/1?pqorigsite=gscholar\&cbl=28224 on March 10, 2020.

Viinikainen, J., Heineck, G., Böckerman, P., Hintsanen, M., Raitakari, O., \& Pehkonen, J. (2017). Born entrepreneurs? Adolescents' personality characteristics and entrepreneurship in adulthood. Journal of Business Venturing Insights, 8, 9-12. https://doi.org/10.1016/j.jbvi.2017.05.001

Zamrudi, Z., \& Yulianti, F. (2020). Sculpting Factor of Entrepreneurship Among University Students in Indonesia. Entrepreneurial Business and Economics Review, 8(1), 33-49. https://doi.org/10.15678/EBER.2020.080102 


\section{Authors}

Basuki prepared the introduction, literature review, material, and method (50\%), while Rahmi Widyanti processed statistical analysis (25\%), and Ismi Rajiani prepared results and discussion and conclusions (25\%).

\section{Basuki}

Associate Professor in the Department of Management Studies, Head of Management Laboratory, Faculty of Economics and Business, lecturer at the Islamic University of Kalimantan (Indonesia). The author of publications on management studies, entrepreneurship, and SMEs. His research interests include entrepreneurship, human resources management, and business strategy.

Correspondence to: Basuki, Islamic University of Kalimantan, Jl. Adhyaksa No.2, Kayutangi, Banjarmasin 70123, Indonesia, e-mail: msibasukidr@gmail.com

ORCID (1) http://orcid.org/0000-0003-1113-7910

\section{Rahmi Widyanti}

Associate Professor in the Department of Management Studies, Head of Master of Management, Postgraduate of the Faculty of Economics and Business, lecturer at the Islamic University of Kalimantan (Indonesia). The author of publications on management studies, organisational behaviour, entrepreneurship, and SMEs. Her research interests include entrepreneurship, marketing, and consumer behaviour.

Correspondence to: Rahmi Widyanti, Islamic University of Kalimantan, Jl. Adhyaksa No.2, Kayutangi, Banjarmasin 70123, Indonesia, e-mail: rahmiwidyanti@yahoo.com

ORCID (1) http://orcid.org/0000-0001-7458-3112

\section{Ismi Rajiani}

Visiting Assistant Professor in the Department of Social Studies, Lambung Mangkurat University Banjarmasin (Indonesia). He published articles on management in the Polish Journal of Management Studies and in Sustainability. His research interests include cultural management, green business, and environmental studies. Correspondence to: Ismi Rajiani, Lambung Mangkurat University, Jl. Kayu Tangi Banjarmasin 70123, Indonesia, e-mail: rajiani@ulm.ac.id ORCID (i) http://orcid.org/0000-0002-4316-0501

\section{Acknowledgements and Financial Disclosure}

We thank the research team from the class members of 2016, coordinated by Ayu Niken Fajriaty. This research was supported by Islamic University of Kalimantan under the supervisory of Division of Research and Community Services, project No. 207F/UNISKA-PUSLIT/VIII/2018.

\section{Conflict of Interest}

The authors declare that the research was conducted in the absence of any commercial or financial relationships that could be construed as a potential conflict of interest.

\section{Copyright and License}

This article is published under the terms of the Creative Commons Attribution - NoDerivs (CC BY-ND 4.0) License http://creativecommons.org/licenses/by-nd/4.0/ 
